\title{
Poultry litter valorization to energy
}

\author{
P. De Filippis, M. Scarsella, N. Verdone, \\ M. Zeppieri \& B. de Caprariis \\ "La Sapienza" University of Rome, Italy
}

\begin{abstract}
Historically manure has found utilization as fertilizer in agriculture because it contributes to the fertility of the soil by adding organic matter and nutrients, such as nitrogen, phosphorus and potassium. However, the current European Directive 91/676 reduces drastically the application of this material as fertilizer due to its high nitrate content. Therefore, identification of alternative eco-friendly disposal routes with potential financial benefits has become the need, and particularly promising is the energetic valorization of these biomasses. Poultry litter represents one of the more challenging bio-fuel feedstock for energy generation, being easy to handle and showing a composition that potentially assures a high energy content and the production of a byproduct (ash) with good fertilizing properties. In this paper an evaluation of the technical and economic feasibility of the energy conversion technologies usable to recover both the potential energy and fertilizer properties of poultry litter was provided. The focus was on the poultry farms of the North-East Italy, where more than half of the national poultry production is concentrated. The preliminary cost analysis suggests that actually energy production from poultry litter is economically viable in the case of large off-site plants only by means of anaerobic digestion, while in the case of small plants operating in situ for a mean holding capacity farm, utilization of gasification appears to be an option.
\end{abstract}

Keywords: manure, poultry litter, energy recovery.

\section{Introduction}

Owing to the population's growth and incomes, along with changing food preferences, the demand for livestock products is continuously increasing, while globalization is boosting trade in livestock inputs and products. Global production of meat and milk is forecasted to double in 50 years from the beginning of this 
century, reaching 465 million tonnes for the meat and overcoming one thousand million tonnes for the milk [1].

The present and future impact of the livestock sector on environmental problems is massive and in this context the management of manure has become one of the most important issues. Historically manure has found utilization as fertilizer in agriculture because it contributes to the fertility of the soil by adding organic matter and nutrients, such as nitrogen, phosphorus and potassium. These disposal methods, however, require proper land application and agronomic rates and soil management to ensure beneficial use and avoid leaching of nitrate and possible transfer of pathogens to the groundwater from fields where high doses of manure have been applied and threatening of soil fertility owing to unbalanced or even noxious nutrients concentrations [2]. As a consequence, land spreading of manure is strictly regulated and in EU the European Directive 91/676 reduces drastically the application of this material as fertilizer.

Therefore, identification of alternative eco-friendly disposal routes with potential financial benefits has become the need. Schemes providing energy and easy to handle fertilizer as a by-product would be the best alternative route.

To this aim poultry litter represents one of the more challenging bio-fuel feedstock for energy generation, being easy to handle and showing a composition that potentially assures a high energy content and the production of a byproduct (ash) with good fertilizing properties.

Commercial poultry production is rapidly expanding growing at 4-5\% per year $[3,4]$ and is expected to continue expansion in the foreseeable future. Nowadays the world magnitude of the poultry industry has reached a total of all types of poultry meat productions of about 86 million ton per year [5]. Increases in the demand of poultry products have led to a growth in the dimensions of poultry farms and to a concentration of production, which has caused excessive manure supplies in certain areas.

Poultry industry is very developed in Italy with a poultry meat production over one million tons per year and an egg production of about 13 billion per year [6]. Moreover, most of the Italian poultry farms are concentrated in a relatively limited part of the national territory. In these areas, a mean holding capacity of about 40000 birds is calculated for the poultry companies, thus giving rise to an urgent need of robust and economical high-volume alternative uses for poultry litter.

\section{Poultry litter material}

Poultry facilities produce litter which is composed primarily of manure, bedding material (wood shavings, saw dust, paper etc.) and feed. Numerous factors determine the quality and composition of the litter, including the used bedding material, the number and type of poultry, the number of flocks per year, the sources of moisture, other than the overall litter management approach. However, whatever the litter composition is, except ash and water the other constituents are all potential energetic materials and poultry litter can be used for power generation directly. Moreover, no fuel preparation is required for poultry litter, except possibly some breaking up of clumps. 
In the present work, two different kind of poultry litter coming from the poultry farms of the North-East Italy, where more than half of the national poultry production is concentrated, were considered. As can be noticed from the values reported in the Table 1, this feedstock presents a high variability of composition that mainly depends on the different materials used for the bedding.

After collection of representative samples, the poultry litter samples were dried in the shadow for one week before characterization. The results of the characterization analysis are reported in table 1 .

Table 1: Main characteristics of the considered poultry litter.

\begin{tabular}{lll}
\hline & Poultry litter 1 & Poultry litter 2 \\
\hline Moisture (mass \%) & 20.2 & 12.5 \\
Volatile substance (mass \% dry basis) & 59.5 & 61.4 \\
Fixed carbon (mass \% dry basis) & 24.9 & 11.2 \\
Ash (mass \% dry basis) & 15.6 & 27.4 \\
LHV (MJ kg-1) & 12.72 & 12.68 \\
\hline Element (mass \% dry basis) & & \\
\hline Carbon & 37.2 & 35.9 \\
Hydrogen & 5.52 & 4.98 \\
Oxygen & 23.0 & 27.38 \\
Nitrogen & 4.4 & 3.56 \\
Sulfur & 0.3 & 0.77 \\
Chlorine & 0.8 & 0 \\
\hline
\end{tabular}

The ash is characterized by an amount of phosphorus as $\mathrm{P}_{2} \mathrm{O}_{5}$ and potassium as $\mathrm{K}_{2} \mathrm{O}$ of $20.2 \%$ and $13.8 \%$, respectively.

\section{Energy conversion technologies}

Three technologies are currently tested as alternatives to land-disposal methods: anaerobic digestion, direct combustion and gasification.

Anaerobic Digestion: it is a biological process where microorganisms convert organic materials to methane, carbon dioxide and other organic compounds in the absence of oxygen [7]. Anaerobic digesters typically consist of large fermentation tanks with mechanical mixing, heating and gas collection. The process can be applied at any site that produces organic materials. The efficiency of conversion of manure to methane gas depends on many factors such as quality of manure, retention time in digester and temperature of the digester [8]. The retention time is strictly dependent on the operating temperature. When the temperature is in the mesophilic range $\left(20-45^{\circ} \mathrm{C}\right)$, the typical retention time is 15 to 30 days, however, operating the process with temperature in the thermophilic range (temperature $>45^{\circ} \mathrm{C}$ ), the retention time can be shortened to 12 to 14 days.

Thermophilic digestion systems offer higher methane production and better virus and pathogen reduction, but require greater energy input and higher cost of operation compared to mesophilic systems [9]. 
In evaluating the anaerobic digestion, the amount of volatile matter is of great importance, because typically only the $60 \%$ of volatile matter is converted to

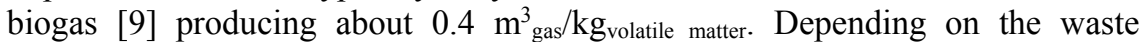
feedstock and the system design, biogas is typically $55-75 \%$ methane. The produced biogas can be used to fuel internal combustion engines that run generators and produce electricity.

When poultry litter is considered, on the basis of its composition an estimated production of $0.22 \mathrm{~m}^{3} / \mathrm{kg}_{\text {litter }}$ of biogas is obtained with a typical heating value of $22.4 \mathrm{MJ} / \mathrm{m}^{3}$. The net electric power generation per MJ of thermal power depends on the method by which the electricity is generated. When a reciprocal engine was considered, a $30 \%$ efficiency conversion was assumed. With these assumptions the net electric power generation is $0.41 \mathrm{kWh} / \mathrm{kg}_{\text {litter }}$.

The cost of an anaerobic-digestion system can vary dramatically depending on its size, intended purposes and sophistication. From the quotation of a European supplier for different anaerobic digester sizes $(10,100$ and $1000 \mathrm{kWe})$ a capital cost equal to $11780 \times\left(\mathrm{kWe}_{\text {installed }}\right)^{0.86}$ is obtained, while the running costs are estimated from the same supplier to be $2600 \times\left(\mathrm{kWe}_{\text {installed }}\right)^{0.53}$ per year.

Direct Combustion: direct combustion is the simplest and most versatile energy conversion technology. Various fuels could be used including different varieties of biomass (e.g., wood, animal manure, agricultural residue and municipal solid waste). It involves the burning of fuel with excess air, producing hot flue gases that are used to produce steam in the heat exchange sections of boilers. Steam is then used to produce electricity in steam turbine generators.

On the basis of biomass combustion plants running in Italy, the conversion efficiency from thermal to electric power is assumed to be $21 \%$ for small plant and $32 \%$ for a plant of $10 \mathrm{MW}$ or higher. Indeed, when poultry litter is considered, the net electricity generation can be estimated equal to $0.74 \mathrm{kWh} / \mathrm{kg}_{\text {litter }}$ or 1.13 $\mathrm{kWh} / \mathrm{kg}_{\text {litter, }}$, respectively.

The capital costs of direct combustion power plants are very sensitive to plant dimension, varying from $10,500 € / \mathrm{kW}$ for a small plant $(100 \mathrm{~kW})$ to $2,100 € / \mathrm{kW}$ for a $10 \mathrm{MW}$ plant. The running costs are estimated to vary from $1,600 € / \mathrm{kW}$ for the former to $146 € / \mathrm{kW}$ for the latter.

It should be noted that when manure is used as fuel an accurate control of emissions is required due to the large amount of $\mathrm{NO}_{\mathrm{X}}$ generated during the process. Staged combustion is a widely used option for lowering $\mathrm{NO}_{\mathrm{X}}$ emissions from a high-nitrogen fuel such as poultry litter. With staged combustion, combustion conditions are somewhat more reducing and less fuel bound nitrogen is converted to $\mathrm{NO}_{\mathrm{X}}$.

Ammonia injection under appropriate conditions also reduces $\mathrm{NO}_{\mathrm{X}}$ emissions, and the naturally occurring ammoniacal nitrogen in poultry litter helps keep $\mathrm{NO}_{\mathrm{X}}$ emissions low. In some cases, more rigorous $\mathrm{NO}_{\mathrm{X}}$ control measures, such as selective catalytic reduction, may be required for poultry litter.

Gasification: in gasification, organic materials are converted into carbon monoxide and hydrogen (i.e., "syngas") that can subsequently be used for the production of a variety of fuels and chemicals. The first step in gasification is pyrolysis where volatile components are vaporized and char (fixed carbon) 
is produced at temperatures under $600^{\circ} \mathrm{C}$. In the second step, the char and volatile products are combusted with oxygen to form $\mathrm{CO}$ and $\mathrm{CO}_{2}$, generating heat for gasification. In the final step, gasification process takes place where the char reacts with $\mathrm{CO}_{2}$ and steam to produce $\mathrm{CO}$ and $\mathrm{H}_{2}$. Hydrogen and carbon monoxide are the desired product gases and they can be directly fired in a reciprocal engine or in a gas turbine for power generation [10].

A typical syngas composition produced from a plant equipped with a fixed bed gasifier having the capacity of about $4000 \mathrm{~kg} / \mathrm{h}$ and using air as gasifying agent is reported in the table 2 .

Table 2: Typical syngas composition.

\begin{tabular}{ll}
\hline & \% volume \\
$\mathrm{CO}$ & $19-22$ \\
$\mathrm{CO}_{2}$ & $10-13$ \\
$\mathrm{H}_{2}$ & $18-20$ \\
$\mathrm{CH}_{4}$ & $0-3$ \\
$\mathrm{~N}_{2}$ & 50 \\
\hline
\end{tabular}

Gasification of poultry litter at a small scale has successfully been demonstrated and the reported overall energy conversion efficiency is estimated to be $30 \%[10,11]$. The capital costs for a $100-500 \mathrm{~kW}$ plant could be estimated as $1700 € / \mathrm{kW}$, with running costs of about $180 € / \mathrm{kW}$.

\section{Economic analysis}

In Italy the poultry litter production of a mean holding capacity farm and that of a district can be estimated at about $300 \mathrm{t}_{\text {litter }} /$ year and 95,000 $\mathrm{t}_{\text {litter }} /$ year, corresponding to a thermal power of about $130 \mathrm{~kW}$ and $38 \mathrm{MW}$ respectively.

The revenue from the sale of the net produced electric power depends on the unit price assumed. In Italy the price is actually under definition and maintained between $0.08-0.15 € / \mathrm{kWh}$. The evaluation was performed considering a mean price of $0.115 € / \mathrm{kWh}$. The specific revenue referred to the unit mass of manure $R_{s p}\left(€ / \mathrm{kg}_{\text {manure }}\right)$ can be easily calculated by

$$
R_{s p}=P_{e e} \times P_{s p}
$$

where $P_{e e}(€ / \mathrm{kWh})$ is the electric power retail price, and $P_{s p}\left(\mathrm{kWh} / \mathrm{kg}_{\text {manure }}\right)$ is the specific electric power generation.

In an economic assessment, it must be considered that both direct combustion and gasification processes produce a by-product, ash, that owing to its content of phosphorus and potassium is a valuable product that can be sold as fertilizer.

The net fertilizer value of poultry litter ash at the energy plant, after accounting for transportation costs, any additional processing costs and marketing costs that may be required, will range from 19 to $60 € / t$ of ash. In this paper a mean value of $40 € / t$ is considered [12]. 
The results relative to the three considered energy conversion processes are reported in table 3 . In the table, a small plant operating in situ for a mean holding capacity farm and an off-site district plant with a treatment capacity of $95,000 \mathrm{t}_{\text {litter }} /$ year were considered. Furthermore a 10 year time frame is considered with a $5 \%$ rate of return.

Table 3: Cost analysis for the three considered energy conversion processes.

\begin{tabular}{|l|c|c|c|c|c|}
\hline & \multicolumn{2}{|c|}{$\begin{array}{c}\text { Anaerobic } \\
\text { digestion }\end{array}$} & \multicolumn{2}{l|}{ Direct combustion } & Gasification \\
\hline Plant rating $\mathrm{kW}$ & 50 & 15000 & 150 & 40000 & 150 \\
\hline Capacity factor $(\%)$ & 93 & 98 & 81 & 95 & 80 \\
\hline Capital costs $€ / \mathrm{kWh}$ & 0.973 & 0.343 & 7.429 & 0.599 & 0.647 \\
\hline Annualized capital costs $€ / \mathrm{kWh}$ & 0.107 & 0.038 & 0.817 & 0.066 & 0.0712 \\
\hline $\mathrm{O} \& \mathrm{M}$ costs $€ / \mathrm{kWh}$ & 0.084 & 0.005 & 1.130 & 0.055 & 0.069 \\
\hline Transportation costs $€ / \mathrm{kWh}$ & 0.000 & 0.031 & 0.000 & 0.013 & 0.000 \\
\hline Total annual costs $€ / \mathrm{kWh} /$ year & 0.191 & 0.073 & 1.947 & 0.134 & 0.140 \\
\hline Ash value $€ / \mathrm{kWh}$ & 0.000 & 0.000 & 0.008 & 0.005 & 0.006 \\
\hline Electric power selling price $€ / \mathrm{kWh}$ & 0.115 & 0.115 & 0.115 & 0.115 & 0.115 \\
\hline Total & -0.076 & 0.041 & 1.824 & 0.014 & -0.019 \\
\hline
\end{tabular}

\section{Conclusions}

The preliminary cost analysis suggests that energy production from poultry litter is actually economically viable only in the case of large off-site plants the anaerobic digesters being the sole that can guarantee a return in a ten year frame. Nevertheless, owing to the increasing cost of electricity, the more and more stringent regulations about land spreading of manures and the growing of the economic value as fertilizer of the residual ash, energy production from poultry litter by direct combustion or gasification will probably appear particularly viable in the very near future.

Energy recovery (electricity and/or process steam) with ash export is a promising high-volume alternative use for poultry litter. Because of nutrient concentration and value in the ash, energy options provide a built-in mechanism for economically exporting surplus of phosphorus and associated nutrients out of concentrated poultry areas.

In the complex it could lead to an improvement of the environmental sustainability of the poultry industry in its service area.

\section{References}

[1] Steinfeld, H., Gerber, P., Wassenaar, T., Castel, V., Rosales, M. \& de Haan, C., Livestock's long shadow: environmental issues and options, Report LEAD/FAO. Rome, 2006.

[2] Cabrera, M.L. \& Sims, J.T., Beneficial use of poultry byproducts: challenges and opportunities. Land Application of Agricultural, Industrial, 
and Municipal Byproducts, eds. J.F. Power \& W.A. Dick, SSSA, Madison, WI, 2000.

[3] Axtell, R.C., Poultry integrated pest management: status and future. Integrated Pest Management, 4, pp. 53-73, 1999.

[4] Windhorst, H.W., Changes in poultry production and trade worldwide. World's Poultry Science Journal, 62, pp. 585-602, 2006.

[5] Food Outlook - November 2007. Series Title: Food Outlook (GIEWS) - 2 2007.

[6] UNA, Unione Nazionale dell'Avicoltura, 2006.

[7] Kelleher, M., Anaerobic digestion outlook for MSW streams. BioCycle, 48(8), p. 51, 2007.

[8] Jenner, M., The biotown, USA sourcebook of biomass energy, Indiana State Department of Agriculture and Reynolds, Indiana, April 2006.

[9] Barker, J.C., Methane fuel gas from livestock wastes: a summary. Publication \#EBAE 071-80. North Carolina State University Cooperative Extension Service, Raleigh, NC, March 2001.

[10] Kwant, K.K. \& Knoef, H., eds., Status of Gasification in Countries participating in the IEA and GasNet Activity, Netherlands, August 2004.

[11] Reardon, J.P., Lilley, A., Browne, K., Beard, K., Wimberly, J. \& Avens J., Demonstration of a small modular biopower system using poultry litter, DOE SBIR Phase-I Final Report, February 25, 2001.

[12] Bock, B., Potential for ash value to make or break a poultry litter energy project. Southern Bio-Products Conference, Jackson, MS, March 22-23, 2005. 